\title{
EFFECT OF PRECONDITIONS AND UNSAFE ACTS ON EVACUATION DURATION IN FIRE DISASTER CONDITIONS (STUDY AT THE INPATIENT BUILDING OF GENERAL HOSPITAL R. KOESMA TUBAN)
}

\author{
Erwin Era Prasetya ${ }^{1}$, Denny Ardyanto W. ${ }^{1}$, Hari Basuki Notobroto ${ }^{2}$, Tjipto Suwandi ${ }^{1}$ \\ ${ }^{1}$ Departement of Occupational Safety and Health, \\ Faculty of Public Health, Airlangga University, Surabaya, Indonesia \\ ${ }^{2}$ Departement of Biostatistics and Demography, \\ Faculty of Public Health, Airlangga University, Surabaya, Indonesia \\ Corespondence Address: Erwin Era Prasetya \\ Email: erwineraprasetya@gmail.com
}

\begin{abstract}
Hospital fires have the potential to cause fatalities and huge material losses, there were 22 hospital fires covered by newspapers in India in 2011-2012 with 102 dead. Buildings are considered safe if all occupants building threatened by fire must be able to exit and assembly point before available safe egress time. This study aimed to analyze the effect of preconditions and unsafe acts (violations of evacuation procedures) on evacuation duration in fire disaster conditions in the inpatient building of general hospital R. Koesma Tuban. This study was an observational study, a quantitative method and cross sectional design, which were carried out in April-July 2019. Analysis of Covariance test results stated preconditions (age, sex, exercise habits, location of inpatient ward, distance traveled) affect the duration of evacuation $(\mathrm{p}<0.05)$ while preconditions (interaction between workers and readiness of workers) don't affect the duration evacuation $(\mathrm{p}>0.05)$. Violation of evacuation procedures has the potential to influence the duration of evacuation $(\mathrm{p}=0.054)$. The conclusions this study are age, gender, exercise habits, location of the inpatient ward, and distance traveled affect the duration of the evacuation.
\end{abstract}

Keywords: Duration of evacuation, preconditions, violations of evacuation procedures, hospital.

\section{INTRODUCTION}

The hospital is a place that has a high risk to the safety and health of hospital human resources, patients, patient companions, visitors, and the hospital environment. So that in the framework of managing and controlling risks related to occupational safety and health in hospitals, it is necessary to organize hospital occupational safety and health in order to create a healthy, safe, secure, and comfortable hospital condition. Indonesian Ministry of Health, 2016)

Fire is an oxidation event that has three elements involved in it, namely combustible fuel, oxygen in the air and a source of heat energy that can cause danger and injury even to death. (NFPA, 2003). Fire at the hospital has the potential to cause fatalities and huge material losses, there were 22 hospital fires covered by newspapers in India with 102 dead (Chowdhury, 2014). The latest hospital fires reported by the British Broadcasting Company (BBC) was on January 26, 2018 at Sejong Hospital, about 380 kilometers southeast of Seoul, South Korea. 41 people died as a result of fire. The most recent case of hospital fires in Indonesia occurred on December 14, 2017 at Kurnia Hospital, Cilegon City, Banten, Indonesia. Sparks from the electrical short circuit in the child's room. The fire was extinguished using a mild fire extinguisher by hospital staff, but the fire grew larger and caused panic throughout the hospital. This happened because in the hospital there were patients who did not allow to save themselves (BBC, 2018).

General Hospital R. Koesma Tuban has four storey inpatient buildings (eight inpatient rooms). In each inpatient room there are 20-33 bed patients with BOR 
(Bed Occupancy Rate) which reaches more than $70 \%$. But the inpatient building has a disadvantage that is the absence of emergency exits, only exits that are not fire resistant. As for fire detectors and alarms in each room, there is only one. And also the absence of emergency lighting on corridors, stairs and ramps. For this reason, the evacuation process in the inpatient building of General Hospital R. Koesma Tuban is more difficult to do and requires quite a long time (Koesma RSUD, 2019).

Preconditions that affect unsafe actions are environmental factors, workers' conditions and personal factors. Workers' conditions include age, sex, and exercise habits. Personal factors are the readiness of workers and interactions between workers. Environmental factors are corridors, emergency exits, ramps, lighting, room location, and the distance of the room to the assembly point (Wiegmann \& Shappell, 2005).

Unsafe acts or unsafe actions are factors that cause accidents. Unsafe actions are defined as active actions or mistakes committed by someone that result in an unsafe situation or event. Unsafe acts are divided into two levels, namely errors and violations (Butler et al., 2017). In this study, the violation are violations of evacuation procedures.

Therefore, the purpose of this study is to analyze the effect of preconditions and unsafe acts (violations of evacuation procedures) on the duration of evacuation under fire disaster conditions in the inpatient building of General Hospital R. Koesma Tuban.

\section{METHODS}

This study was a research that used quantitative methods and types of observational research because researchers only observed subjects to conduct evacuation simulations without intervening or giving treatment. The evacuation simulations were done in the inpatient building of general hospital R. Koesma Tuban, namely Teratai, Asoka, Mawar, Anggrek, Bougenvil, Dahlia, Anyelir and Melati rooms. This study was conducted in April-July 2019. The population was a team of employees (nurses and non-nurses) in 8 inpatient rooms totaling 129 people. To evacuate a patient, 2 inpatient employees were needed to get 64 teams to become the study population. Sampling of research from existing populations was then performed sample calculations using the Lemeshow formula, so that a sample of 50 teams was obtained. The sampling technique was obtained randomly (Levy, P. S., \& Lemeshow, S. 2009). The sampling technique was obtained randomly with the exclusion criteria of employees who had a history of heart disease.

Data collection techniques used were primary data that includes evacuation time obtained from evacuation simulations, physiological conditions of workers (age, sex, sports habits) and personal factors (worker readiness, interaction between workers) obtained through a questionnaire containing the characteristics of respondents including age, sex, exercise habits, interaction between workers and readiness of workers in the inpatient room. Interaction questionnaire between workers and worker readiness were adopted from Hamid's research (2017). Then the results of the questionnaire were analyzed using statistical tests. As for environmental data such as (corridors, emergency exits, ramps, lighting, room location, and the distance of the room to the assembly point) as well as infrastructure especially those that support evacuation in the event of a fire disaster were obtained with observation sheets related to standards in accordance with the Hospital Building Technical Guidelines that safe in emergencies and disasters, Minister of Health Number 1691 Year 2011 concerning Hospital Patient Safety and Minister of Health Decree Number 1087 concerning Occupational Health and 
Safety Standards in Hospitals. Observation data in this study were taken by UPT K2 Surabaya and the researchers.

Unsafe actions or violations of the evacuation procedure were obtained with an observation sheet related to the evacuation procedure when an evacuation simulation was carried out. Evacuation simulations were carried out by 2 inpatient staff, starting from moving the patient (played by hospital staff) from the inpatient bed to the brancard then the patient was evacuated to the assembly point. Secondary data used were hospital profiles, inpatient staff data, and evacuation procedure. The certificate of ethics was issued by the Health Research Ethics Commission of the Faculty of Public Health, Airlangga University with the certificate number of ethics 136 / EA / KEPK / 2019.

\section{RESULTS}

\section{Characteristics of respondents}

The characteristics of respondents measured here were based on age, sex, and exercise habits, shown in Table 1.

Table 1. Distribution of Respondent Characteristics

\begin{tabular}{lcccccc}
\hline \multirow{2}{*}{\begin{tabular}{c} 
Characteristics of \\
\multicolumn{1}{c}{ respondents }
\end{tabular}} & \multicolumn{2}{c}{ Nurse } & \multicolumn{2}{c}{ Non-Nurse } & \multicolumn{2}{c}{ Total } \\
\cline { 2 - 7 } & Amount & \% & Amount & \% & Amount & $\%$ \\
\hline Usia & & & & & & \\
$\leq 25$ y.o & 14 & 15.7 & 1 & 9.1 & 15 & 15 \\
26-35 y.o & 47 & 52.8 & 2 & 18.2 & 49 & 49 \\
$\geq 36$ y.o & 28 & 31.5 & 8 & 72.7 & 36 & 36 \\
Average Age (y.o) & 32.12 & & 38.36 & & 32.81 & \\
\hline Sex & & & & & & \\
Male & 20 & 22.5 & 5 & 45.5 & 25 & 25 \\
Female & 69 & 77.5 & 6 & 54.5 & 75 & 75 \\
\hline Exercise Habits & & & & & & \\
$\leq$ once a week (rarely) & 60 & 67.4 & 7 & 63.6 & 67 & 67 \\
Twice a week (sometimes) & 21 & 23.6 & 2 & 18.2 & 23 & 23 \\
3-5 times a week (often) & 8 & 9 & 2 & 18.2 & 10 & 10 \\
\hline
\end{tabular}

Source: Primary Data, 2019

Based on the research results presented in Table 1, the average age was 32.81 y.o, with an average age of nurses 32.12 y.o, and the average age of nonnurses was 38.36 y.o. The highest number at the age range of 26-35 years was as much as $49 \%$. Nurses gender were $22.5 \%$ male and $77.5 \%$ female. Non-nurses gender were $45.5 \%$ male and $54.5 \%$ female. While the exercise habits of nurses $67.4 \%$ were less than or equal to once a week and the exercise habits of non-nurses $63.6 \%$ were less than or equal to once a week. This showed that the majority of nurses and non-nurses only exercise less than or equal to once a week.

\section{Precondition}

The results of the study of the average duration of the evacuation based on the Precondition variables (age, sex, exercise habits, inpatient room location, distance to assembly point, interaction between workers, and readiness of workers) would be presented in Table 2 . 
Table 2. Average Evacuation Time Based On Precondition Variables

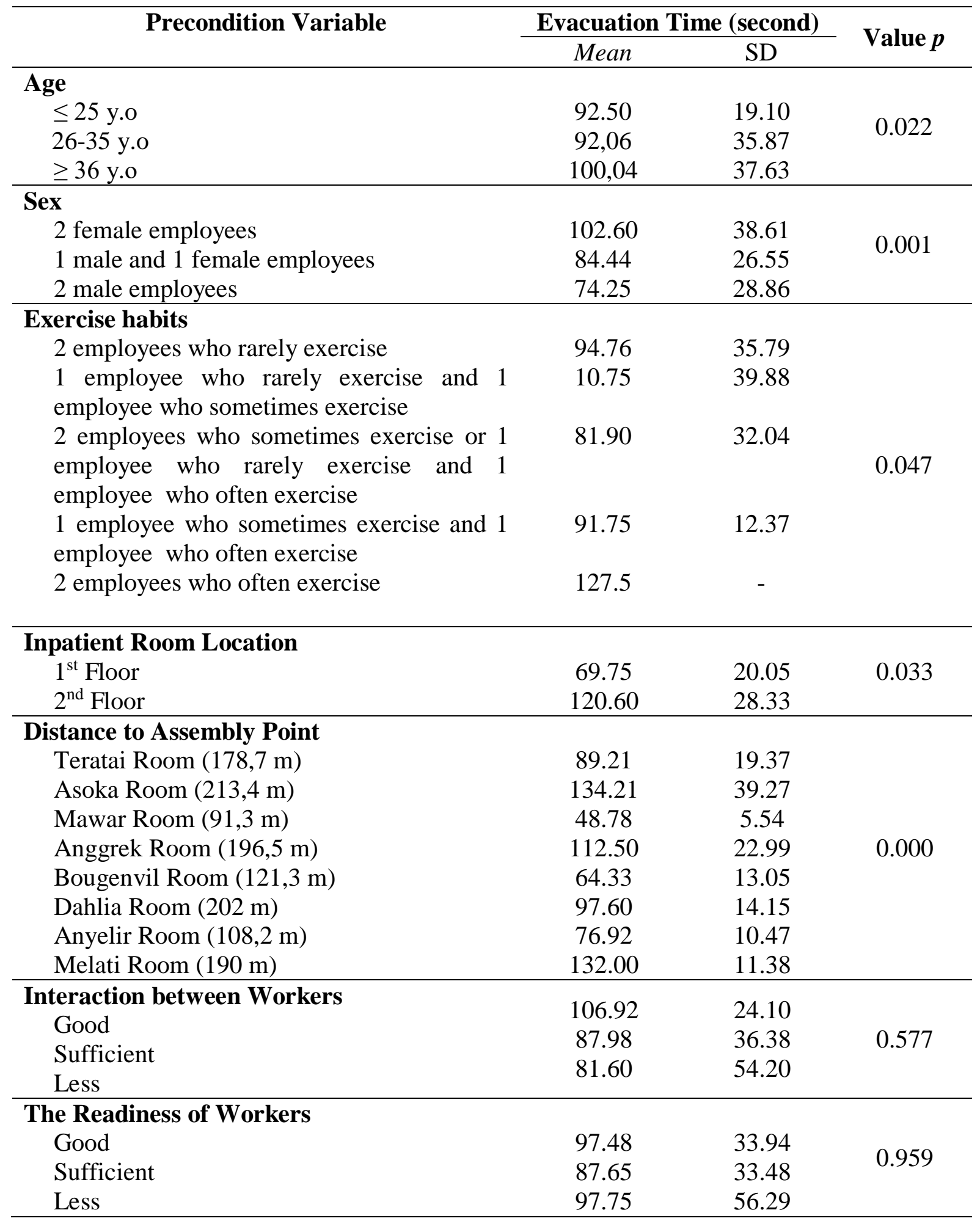

Source: Primary Data, 2019

Based on Table 2, the average duration of evacuation on the team of employees with an average age of less than or equal to 25 y.o and 26-35 y.o did not differ greatly, namely 92.50 seconds and 92.06 seconds. Evacuation time increased to 100.04 seconds on the employee team with an average age of more than or equal 
to 36 years. The average evacuation time was faster in the gender mix of the team of 2 male employees (74.25 seconds) compared to the team of male and female employees (84.44 seconds) and 2 women (102.60 seconds). While the average evacuation time was the fastest $(81.90$ seconds) on teams with 2 employees sometimes sports or 1 employee rarely and 1 employee often sports. The average evacuation time was the slowest (127.5 seconds) on teams with 2 employees often exercising. This happened because there was only 1 team with 2 employees who often exercise and the employee worked in the Asoka room on the 2nd floor and the farthest distance.

Based on the location of the room, the average evacuation time in the first floor inpatient was faster (69.75 seconds) than in the second floor inpatient (120.60 seconds). The distance of the room with the farthest assembly point was the Asoka room which was located on the second floor with a distance of $213.4 \mathrm{~m}$ and required the longest evacuation time (134.21 seconds), while Mawar room which was located on the first floor with a distance of $91.3 \mathrm{~m}$ and took time the fastest evacuation (48.78 seconds).

The average evacuation time for less interactions between workers was the shortest (81.60 seconds), and the average evacuation time for good interactions between workers was the slowest (106.92 seconds). The average evacuation time was faster for workers with sufficient readiness (87.65 seconds) compared to workers with good preparedness (97.48 seconds) and workers with less preparedness (97.75 seconds) in the face of a fire disaster in the room inpatient.

Based on the Analysis of Covariance, it was found that the average age characteristics of the team of employees during evacuation affected the duration of fire evacuation with a value of $p=0.022$. The sex characteristics of the employee team influenced the duration of fire evacuation with a value of $p=0.001$.
Exercise habits also affected the duration of the evacuation with a significance value of $p=0.047$. The location of the inpatient room affected the duration of the evacuation with a value of $p=0.033$ and the distance to the assembly point also affected the duration of the evacuation with a value of $p=0,000$. Interaction factors between workers and worker readiness did not affect the duration of the evacuation. This was indicated by the value of $p>0.05$ on interaction between workers $\mathrm{p}=0.577$ and readiness of workers $\mathrm{p}=0.959$.

\section{Environmental Factors}

The results of observations of environmental conditions in the inpatient room includes; Corridors are safe lanes established to reach the assembly point in the event of a disaster. The size of the corridor as horizontal access is considered based on the corridor function, spatial function, and number of users. Hospital corridor requirements include the width of the corridor with a minimum access of patient beds of $2.4 \mathrm{~m}$, non-slippery and barrier-free floors. The following observations on the corridor were presented in Table 4.

Based on Table 4, there were 3 elements of examination of the corridor, 5 inpatient rooms (Mawar, Bougenvil, Dahlia, Anyelir and Melati) in accordance with the standard while 3 inpatient rooms (Teratai, Asoka and Anggrek) there were 1 element that was not in accordance with the standard namely the corridor was not barrier-free. This matter caused by the large number of patients in the three rooms, so there were patients treated in the corridor

The emergency exit that was the focus of this research was the exit of the inpatient room which was the main access to the ramp and or hallway, as a means of escape to the evacuation route so that it quickly exited to the assembly point. There were various requirements at the exit, including the fire-resistant door, the 
direction of the door opening inside, width, the door is not locked, the door automatically closes and the door is not blocked, as presented in Table 5

Table 4. Observation Result of Inpatient Room Corridor General Hospital R. Koesma

\begin{tabular}{lcccccccc}
\hline \multirow{2}{*}{ Element } & \multicolumn{7}{c}{ R o o m } \\
\cline { 2 - 9 } & Teratai & Asoka & Mawar & Anggrek & Bougenvil & Dahlia & Anyelir & Melati \\
\hline Corridor & 2,75 & 2,75 & $2,75 \mathrm{~m}$ & $2,75 \mathrm{~m}$ & 2,75 & 2,75 & $2,75 \mathrm{~m}$ & $2,75 \mathrm{~m}$ \\
width & and & and & & & and $3 \mathrm{~m}$ & and & & \\
$\geq 2,4 \mathrm{~m}$ & $3 \mathrm{~m}$ & $3 \mathrm{~m}$ & & & & $3 \mathrm{~m}$ & & \\
$\begin{array}{l}\text { non- } \\
\text { slippery }\end{array}$ & $\sqrt{ }$ & $\sqrt{ }$ & $\sqrt{ }$ & $\sqrt{ }$ & $\sqrt{ }$ & $\sqrt{ }$ & $\sqrt{ }$ & $\sqrt{ }$ \\
$\begin{array}{l}\text { floors } \\
\text { barrier-free } \\
\text { floors }\end{array}$ & $\mathrm{X}$ & $\mathrm{X}$ & $\sqrt{ }$ & $\mathrm{X}$ & $\sqrt{ }$ & $\sqrt{ }$ & $\sqrt{ }$ & $\sqrt{ }$ \\
\hline
\end{tabular}

Source: Primary Data, 2019

Table 5. Observation Result of the Exit in the Inpatient Room of General Hospital R. Koesma

\begin{tabular}{|c|c|c|c|c|c|c|c|c|}
\hline \multirow[t]{2}{*}{ Element } & \multicolumn{8}{|c|}{ Roo m } \\
\hline & Teratai & Asoka & Mawar & Anggrek & Bougenvil & Dahlia & Anyelir & Melati \\
\hline $\begin{array}{l}\text { Fire-resistant } \\
\text { door }\end{array}$ & $\mathrm{X}$ & $\mathrm{X}$ & $\mathrm{X}$ & $\mathrm{X}$ & $\mathrm{X}$ & $\mathrm{X}$ & $\mathrm{X}$ & $\mathrm{X}$ \\
\hline $\begin{array}{l}\text { The direction of } \\
\text { the door opening }\end{array}$ & $\mathrm{X}$ & $X$ & $X$ & $X$ & $X$ & $X$ & $X$ & $X$ \\
\hline $\begin{array}{l}\text { Door width }>122 \\
\mathrm{~cm}\end{array}$ & $180 \mathrm{~cm}$ & $180 \mathrm{~cm}$ & $160 \mathrm{~cm}$ & $160 \mathrm{~cm}$ & $180 \mathrm{~cm}$ & $180 \mathrm{~cm}$ & $160 \mathrm{~cm}$ & $160 \mathrm{~cm}$ \\
\hline $\begin{array}{l}\text { The door is not } \\
\text { locked }\end{array}$ & $\sqrt{ }$ & $\sqrt{ }$ & $\sqrt{ }$ & $\sqrt{ }$ & $\sqrt{ }$ & $\sqrt{ }$ & $\sqrt{ }$ & $\sqrt{ }$ \\
\hline $\begin{array}{l}\text { The door } \\
\text { automatically } \\
\text { closes }\end{array}$ & $\mathrm{X}$ & $\mathrm{X}$ & $X$ & $X$ & $X$ & $X$ & $X$ & $X$ \\
\hline $\begin{array}{l}\text { The door is not } \\
\text { blocked, always } \\
\text { in good condition } \\
\text { and ready to use }\end{array}$ & $\sqrt{ }$ & $\sqrt{ }$ & $\sqrt{ }$ & $\sqrt{ }$ & $\sqrt{ }$ & $\sqrt{ }$ & $\sqrt{ }$ & $\sqrt{ }$ \\
\hline
\end{tabular}

Source: Primary Data, 2019

Based on Table 5, there were 6 elements of inspection of the exit. Three elements were not in accordance with the standards, namely the door was not fire resistant, the direction of the door opening inside and the door could not close automatically.
Ramps were located in multi-story inpatient buildings to evacuate weak patients and must be evacuated using a wheelchair and brancard. The results of ramp observations at General Hospital R. Koesma based on the ramp requirements that must be completed were presented in Table 6. 
Table 6. Ramp Observation Results of General Hospital R. Koesma

\begin{tabular}{|c|c|c|}
\hline \multirow[t]{2}{*}{ Elemen } & \multicolumn{2}{|c|}{$R a m p$} \\
\hline & $\begin{array}{l}\text { Ramp between Asoka } \\
\text { and Anggrek Room }\end{array}$ & $\begin{array}{l}\text { Ramp between Dahlia } \\
\text { and Melati Room }\end{array}$ \\
\hline $\begin{array}{l}\text { The slope of the ramp outside the building } \leq \\
6^{\circ}\end{array}$ & $4,9^{\circ}$ & $5,4^{\circ}$ \\
\hline $\begin{array}{l}\left.\text { Horizontal length of one ramp (slope } 7^{\circ}\right) \leq \\
900 \mathrm{~cm} \text {. The length of the ramp with a lower } \\
\text { slope can be longer }\end{array}$ & $\sqrt{ }$ & $\sqrt{ }$ \\
\hline $\begin{array}{l}\text { The minimum width of the ramp is } 95 \mathrm{~cm} \\
\text { and } 120 \mathrm{~cm} \text { with the safety edge }\end{array}$ & $150 \mathrm{~m}$ & $150 \mathrm{~m}$ \\
\hline The ramp bordes must be free and flat & $\sqrt{ }$ & $\sqrt{ }$ \\
\hline The floor surface of the ramp is not slippery & $\sqrt{ }$ & $\sqrt{ }$ \\
\hline The ramp is illuminated with sufficient lighting & $\sqrt{ }$ & $\sqrt{ }$ \\
\hline The ramp is equipped with handrail & $\sqrt{ }$ & $\sqrt{ }$ \\
\hline
\end{tabular}

Source: Primary Data, 2019

Table 7. Lighting Intensity Measurement Results of General Hospital R. Koesma

\begin{tabular}{|c|c|c|c|}
\hline \multirow[t]{2}{*}{ Measurement Location } & \multirow{2}{*}{$\begin{array}{l}\text { Hours } \\
\text { (WIB) }\end{array}$} & \multicolumn{2}{|c|}{ Lighting Intensity (Lux) } \\
\hline & & Local (Average) & General (Average) \\
\hline \multicolumn{4}{|l|}{ Daytime Measurement } \\
\hline Teratai & 13.30 & 85 & 82 \\
\hline Asoka & 13.40 & 214 & 182 \\
\hline Anggrek & 13.50 & 270 & 166 \\
\hline Ramp Anggrek-Asoka & 14.05 & 1971 & 2643 \\
\hline $\begin{array}{l}\text { The Hallway Teratai - Mawar - } \\
\text { Assembly Point }\end{array}$ & 14.20 & 934 & 652 \\
\hline Mawar & 14.30 & 179 & 143 \\
\hline Bougenvil & 14.40 & 107 & 104 \\
\hline Dahlia & 14.50 & 183 & 208 \\
\hline Melati & 15.00 & 632 & 978 \\
\hline Ramp Dahlia-Melati & 15.10 & 608 & 1659 \\
\hline Anyelir & 15.15 & 101 & 104 \\
\hline $\begin{array}{l}\text { The Hallway Anyelir - IGD - } \\
\text { Assembly Point }\end{array}$ & 15.35 & 1015 & 882 \\
\hline \multicolumn{4}{|l|}{ Nightime Measurement } \\
\hline Ramp Anggrek-Asoka & 18.35 & 43 & 67 \\
\hline $\begin{array}{l}\text { The Hallway Teratai - Mawar - } \\
\text { Assembly Point }\end{array}$ & 18.45 & 16 & 70 \\
\hline Ramp Dahlia - Melati & 19.15 & 59 & 75 \\
\hline $\begin{array}{l}\text { The Hallway Anyelir - IGD - } \\
\text { Assembly Point }\end{array}$ & 19.55 & 34 & 47 \\
\hline $\begin{array}{l}\text { Source: Primary Data, } 2019 \\
\text { Based on Table } 6 \text {, there } \\
\text { inspection elements to the ramp } \\
\text { elements were in accordance }\end{array}$ & $\begin{array}{l}\text { re } 7 \\
\text { all } \\
\text { the }\end{array}$ & $\begin{array}{l}\text { standard. Emerg } \\
\text { evacuation route } \\
\text { occupants need a }\end{array}$ & $\begin{array}{l}\text { lighting on th } \\
\text { must continue or } \\
\text { ans of escape. In eac }\end{array}$ \\
\hline
\end{tabular}


inpatient room only had 1 emergency light placed on the nurse station that lights up when the electricity went out. The results of measurements of lighting intensities carried out under normal conditions were presented in Table 7.

Based on Table 7, the results obtained that the light intensity in 8 inpatient rooms, evacuation routes and assembly points were still in accordance with the minimum light intensity level of 5 lux for emergency lighting. Assembly Point or evacuation zone general hospital R. Koesma for the purposes of evacuating patients and officers during a disaster / mass disaster in the hospital there are 4 zones. Zone 1 (the assembly point in front of the emergency room, includes: Anyelir and Melati rooms). Zone 2 (Assembly point in front of the south outpatient building). Zone 3 (assembly point in front of the west outpatient building). Zone 4 (the assembly point in front of the mortuary which includes: rooms Teratai, Asoka, Mawar, Anggrek, Bougenvil dan Dahlia).

\section{Unsafe acts}

Unsafe acts or in this study were violations of the evacuation procedure committed by a team of employees. The results of observations of the team of employees who committed violation of evacuation procedures were presented in Table 8.

Based on Table $8,40 \%$ of the employee team violated of evacuation procedures (moderate and low). This could be seen from the use of high-heeled shoes, how to move the patient to the brancard, forgetting to remove the lock on the brancard wheel, how to push the brancard, how to turn the brancard, how to stop the brancard and teamwork. Analysis of Covariance results was significance value of $\mathrm{p}=0.054$ which means violation of evacuation procedures during evacuation had a potential influence on the duration of evacuation during a fire.

Table 8. Observation Results of Employee Team Compliance to Evacuation Procedures during Evacuation

\begin{tabular}{lcc}
\hline $\begin{array}{l}\text { Compliance to } \\
\text { Evacuation } \\
\text { Procedures }\end{array}$ & Total & $\%$ \\
\hline Good & 30 & 60 \\
Moderate & 16 & 32 \\
Low & 4 & 8 \\
\hline
\end{tabular}

Source: Primary Data, 2019

\section{DISCUSSION}

According to Wiegmann and Shappell Preconditions or preconditions of unsafe actions are certain conditions that cause unsafe acts (Wiegmann \& Shappell, 2003). Preconditions for unsafe actions include environmental factors, worker conditions and personal factors. According to Kasereka, factors that can affect the speed of evacuation are emotions, physical limitations, stress, wind speed, age and gender (Kasereka et al., 2018).

The results of this study indicate that there is an influence of age on the duration of evacuation in fire conditions in the inpatient room of General Hospital R. Koesma Tuban. Where the relatively young age is less or equal to 25 years and 26-35 years, the evacuation time tends to be the same, which is faster than the age of more or equal to 36 years. This is consistent with previous research that the average speed of movement of visitors when descending stairs and aisles under normal conditions at an average density of 2.9 people $/ \mathrm{m}^{2}$ is $0.15 \mathrm{~m} / \mathrm{s}$ for graduates and graduates and $0.13 \mathrm{~m} / \mathrm{s}$ for male parents and women (Chu et al., 2019).

Characteristics based on the sex of the team of inpatient staff during the evacuation simulation also affected the duration of the evacuation in the fire conditions in the inpatient room of General 
Hospital R. Koesma Tuban. This is consistent with previous research which states that there are differences in the speed of walking of the population during the evacuation process based on gender and age.The average walking speed of young men is $1.32 \mathrm{~m} / \mathrm{s}$ while young women are $1.27 \mathrm{~m} / \mathrm{s}$. There is a difference of $0.05 \mathrm{~m} / \mathrm{s}$ between men and women of the same age (Chu et al., 2019).

Cardiorespiratory capacity (CRC) is the main indicator of human physical limits.

Repeated muscle activity during evacuation can cause local muscle fatigue (LMF) or local muscle fatigue that affects the speed and duration of evacuation.CRC and LMF are influenced by one's sporting habits. The more a person exercises, the greater the CRC and it takes a long time for LMF to occur (Halder et al., 2018).

In this study shows that employee exercise habits affect the duration of the evacuation. Where someone with a habit of exercising has the potential to be able to get quickly to the meeting point when a fire disaster occurs. This is consistent with previous research that there is an influence between the form of contrast training with 100 meters running speed and optimal stride length. The contrast exercise in question is a resistance exercise that causes the muscles to contract which aims to increase the strength of the body's endurance. So as to be able to do work at a higher level. When someone has a habit of exercising, it will indirectly affect the strength and speed of someone to run to the point of assembly when there is a fire (Rumini et al., 2012).

The location of the inpatient rooms which consists of 1 st floor and 2nd floor are connected by a special ladder for employees and ramps. The distance to the second floor inpatient room is $50 \mathrm{~m}$ longer because it passes through the ramp during evacuation so the evacuation duration value becomes large. In this study shows the location of floor space 1 and 2 affect the duration of the evacuation during a fire disaster. This is not much different from previous studies that the time needed for evacuation to the assembly point of the 2nd floor of the building is longer than the 1 st floor during an emergency situation (Andhika et al., 2013).

Distance to assembly point in this study is from the patient's bed in the inpatient room to the assembly point. In this study shows that distance to assembly point influences the evacuation duration during the evacuation simulation

Interaction between workers is needed as a communication medium when we work, but apparently in the evacuation process it is not directly related. In the event of a fire disaster, all inpatient staff only prioritize the evacuation process as quickly as possible to the meeting point, without seeing the pair in the team. The results showed that there was no influence between the interaction of workers with the duration of the evacuation. This is different from previous research that in disaster emergency conditions communication is needed as a function of management and coordination (Rudianto, 2015)

Worker readiness includes staff readiness and knowledge of patient evacuation procedures. In the process of evacuation from a fire disaster, the safety of the occupants of the building is primary. In this study, employee readiness did not affect the duration of the evacuation. This is almost the same as previous research that community preparedness is at a high level. In an emergency situation the community tends to take actions that can minimize the impact of the disaster. Community preparedness during emergencies is influenced by community knowledge about what is done when a disaster occurs and knowledge about disaster risk is still lacking (Dodon, 2013).

Based on environmental factors in the inpatient corridor, the corridor floor is not slippery and the width of the corridor is different. Inpatient corridors are barrierfree except Asoka, Teratai and Anggrek. In these three rooms, there is often a buildup 
of patients to be treated in the corridor. This patient buildup can hinder the evacuation process and endanger patient safety. This is not in accordance with Minister of Health Regulation number 1691 Year 2011 concerning Hospital Patient Safety.

Inpatient room of General Hospital R. Koema does not have an emergency exit specifically. Emergency door here is the main exit from the inpatient room which is the main access to the ramp and or hallway that can be passed by the brancard. The main door is unlocked, unobstructed, always in good condition and ready to use. The width of the door is $180 \mathrm{~cm}$ in the Asoka, Teratai, Bougenvil and Dahlia rooms while the Mawar, Anggrek, Anyelir and Melati rooms have 160 door widths.

Next to the main door, there are different exit doors in each inpatient room. The Asoka, Teratai, Mawar and Anggrek rooms have 10 exits. The Bougenvil and Dahlia rooms have 8 exits. The Anyelir and Melati rooms have 7 exits. The width of the door is at least $122 \mathrm{~cm}$ and the large number of doors is intended so that patients, staff, patient companions, and visitors can be evacuated quickly in the event of a fire disaster.

Three elements that are not in accordance with the standard are the door made of aluminum and glass that is not fire resistant, the direction of the door opening inside and the door cannot close automatically. This is not in accordance with the Technical Guidelines for Building Hospitals that are Safe in Emergencies and Disasters (Indonesian Ministry of Health, 2012) and Minister of Public Works and Human Settlements Regulation Number 26 Year 2008 concerning Technical Requirements of Fire Protection Systems in Buildings and the Environment (Indonesian Ministry of Public Works and Human Settlements, 2008). Standards for emergency doors include fire-resistant doors, internal door opening, wide, door unlocked, automatic door closing and unobstructed door.

The inpatient rooms have 2 ramps which are located in a multi-storey inpatient building. The first ramp connects the Asoka and Anggrek rooms while the second ramp connects the Dahlia and Melati rooms. The results of observations on both ramps obtained a slope angle of $4.9^{\circ}$ and $5.4^{\circ}$. The slope angle of the ramp must be considered during the construction of the ramp so as not to endanger the patient especially during the evacuation process. The width of the second ramp is $150 \mathrm{~m}$, the landing bord is free and flat, the floor surface is not slippery, sufficient lighting (day and night) and equipped with handrails. The results of the observation of the ramp are in accordance with Minister of Health Decree Number 1087 Year 2010 concerning Health and Safety Standards at the Hospital, namely: the slope of the ramp outside the building $\leq 6^{\circ}$, horizontal length of one ramp (slope $7^{\circ}$ ) $\leq 900 \mathrm{~cm}$, the length of the ramp with a lower slope can be longer, the minimum width of the ramp is $95 \mathrm{~cm}$ and $120 \mathrm{~cm}$ with the safety edge, The ramp bordes must be free and flat, the floor surface of the ramp is not slippery, the ramp is illuminated with adequate lighting and the ramp is equipped with handrail.

Lighting in normal conditions is obtained by the intensity of lighting in 8 inpatient rooms, evacuation routes and assembly points during the day above 100 lux except the Teratai room which has a local lighting intensity (average) of 85 lux and general 82 lux. At night, the intensity of the ramp lighting, the lobby and the meeting point 16-75 lux. Ramp and hallway are outside the building so that it gets light from around. This is in accordance with Permenaker Number 5 Year 2018 concerning Occupational Safety and Health at Work Environment which has a minimum light intensity standard of 5 lux for emergency lighting. 
The closest assembly point in the inpatient room is the assembly point in zone 1 and zone 4 . The assembly point in that zone already has the words "Assembly Point" and there is a fairly wide area available (area $>0.3 \mathrm{~m}^{2} /$ person), safe from falls or other hazards, the location is easy to reach and does not preclude danger handling vehicles. In zone 1, the car park is sometimes closed and becomes narrow.

Unsafe acts (violations of evacuation prosedur) or unsafe actions are factors that cause accidents. Unsafe actions are defined as active actions or mistakes committed by workers which result in unsafe situations or events (Wiegmann \& Shappell, 2003). In this study shows that there are still employees who violate evacuation procedure. This violation of the evacuation procedure occurs because employees in the inpatient room forget and rarely reopen the evacuation procedure in each room. While the socialization about fire handling and evacuation simulation is only done once a year and is not evenly distributed throughout the entire room / unit / installation, so that makes the staff in the inpatient room less understand and not accustomed when facing an emergency during a fire. Dissemination standards regarding fire handling and evacuation simulations are carried out once a year at all levels at the internal hospital level (Hospital Accreditation Commission, 2018).

\section{CONCLUSION}

The conclusion of this study is preconditions such as age, sex and exercise habits affect the duration of the evacuation during a fire disaster. Building location and distance can also affect the duration of the evacuation during a fire disaster. While the interaction between workers and the readiness of workers does not affect the duration of the evacuation during a fire disaster. There are some environmental factors including infrastructure that do not meet the standards, so that they need immediate improvement to support the safety of patients and staff during the evacuation process. Unsafe acts (violations of evacuation procedure) at the time of evacuation have the potential to influence the duration of the evacuation during a fire disaster. Expected to General Hospital R. Koesma Tuban can provide socialization or fire evacuation simulation at least once a year and be comprehensive to all employees. In subsequent studies, it can be carried out an assessment of other factors that can affect the duration of the evacuation during a fire.

\section{REFERENCES}

Andhika, P. K., Kasim, F., Hawibowo, S., Grafika, J., \& Indonesia, Y. (2013). Optimization of Evacuation Process in Facing Emergency Situations at Graha Sabha Pramana Building (Case Study of Graduation Ceremony). Jurnal TEKNOFISIKA, 2(2), 35-41.

BBC Account. (26 January 2018). The Most Deadly Fire at a Korean Hospital.

Butler, K., Kuligowski, E., Furman, S., \& Peacock, R. (2017). Perspectives of occupants with mobility impairments on evacuation methods for use during fire emergencies. Fire Safety Journal, 91(April), 955-963. https://doi.org/10.1016/j.firesaf.2017. 04.025

Chowdhury, K. (2014). Fires in Indian hospitals: Root cause analysis and recommendations for their prevention. Journal of Clinical Anesthesia, 26(5), 414-424. https://doi.org/10.1016/j.jclinane.201 3.12.014

Chu, H., Yu, J., Wen, J., Yi, M., \& Chen, Y. (2019). Emergency evacuation simulation and management optimization in urban residential communities. Sustainability (Switzerland), 11(3). https: // doi.org / 10.3390 / su11030795 
Dodon. (2013). Indicators and behavior of community preparedness in densely populated settlements in anticipation of various phases of the flood disaster. Jurnal Perencanaan Wilayah dan Kota 24(2), 125-140.

General Hospital R. Koesma Tuban. Hospital Profile. Tuban: General Hospital R. Koesma

Halder, A., Kuklane, K., Gao, C., Miller, M., Delin, M., Norén, J., \& Fridolf, K. (2018). Limitations of oxygen uptake and leg muscle activity during ascending evacuation in stairways. Applied Ergonomics, 66, 52-63. https://doi.org/10.1016/j.apergo.2017. 08.003

Hamid, A. (2017). Effectiveness of Vertical Transportation (Emergency Stairs and Ramp) as a Safety Facility for Intensive Care Patients in Emergency Conditions. Thesis. Surabaya: FKM Airlangga University, Program Study Occupational Health and Safety.

Hospital Accreditation Commission. (2018). National Accreditation Standards for Hospitals. Jakarta: Hospital Accreditation Commission

Indonesian Minister of Public Works and Human Settlements. (2008). Minister of Public Works and Human Settlements Regulation Number 26 Year 2008 concerning Technical Requirements for Fire Protection Systems in Buildings and the Environment. Jakarta.

Indonesian Ministry of Health. (2012). Hospital Infrastructure Technical Guidelines. Jakarta: Directorate of Medical Support Services Development

Indonesian Ministry of Health. (2016). Minister of Health Regulation Number 66 Year 2016 concerning Hospital Occupational Safety and Health. Jakarta.

Kasereka, S., Kasoro, N., Kyamakya, K.,
Doungmo Goufo, E. F., Chokki, A. P., \& Yengo, M. V. (2018). AgentBased Modelling and Simulation for evacuation of people from a building in case of fire. Procedia Computer Science, 130, 10-17. https://doi.org /10.1016/j.procs.2018.04.006

Levy , P. S., \& Lemeshow, S. (2009). Sampling of Populations Methods and Applications: Wiley, USA.

National Fire Protection Association (NFPA), (2003). Fire Protection Handbook Nineteenth Edition I Volume $1 \& 2$. Quincy, Massachusetts Rudianto. (2015). Communication in Disaster Management. Jurnal Simbolika, (1), 1-12. https://doi.org/10.1139/T08-100

Rumini., Ks, S., Lumintuarso, R., \& Rahayu, S. (2012). Effect of Training Methods, Forms of Speed and Agility Training on 100-meter Running Achievements. Media Ilmu Keolahragaan Indonesia, 2(1).

Wiegmann, D. A., \& Shappell, S. A. (2005). a Human Error Approach to Aviation Accident Analysis: The Human Factors Analysis and Classification System. Burlington, USA. 